\title{
Gamification in Enterprise Information Systems: What, Why and How
}

\author{
Jakub Swacha \\ University of Szczecin, Faculty of Economics and Management \\ Institute of Information Technology in Management \\ ul. Mickiewicza 64, 71-101 Szczecin, Poland \\ Email: jakubs@uoo.univ.szczecin.pl
}

\begin{abstract}
With gamification, design elements known from games can be used to increase employees' engagement and improve users' experience. This paper points to Enterprise Information Systems as a viable point of implementation of gamification. There are three relevant questions: what gamification actually consists of, why it is worthwhile to apply it in Enterprise Information Systems, and how to implement it properly. The paper aims to answer them.
\end{abstract}

\section{INTRODUCTION}

$\mathrm{F}$ OURTEEN years have passed since Nick Pelling coined the term of gamification [1, p. 5]. The "use of game elements to increase engagement and make life and work more fun" (as it was neatly defined by Mark Schreiber [2]), despite the criticism (see e.g. [3, p. 18] and works cited therein), has already found its way into such diverse areas as, among others, marketing [4] and knowledge management [5], banking [6] and education [7], production environments [8] and tourism [9], and even scientific research [10].

This paper investigates the application of gamification in Enterprise Information Systems (EIS), understood as "software systems that integrate the business processes of organizations to improve their functioning" [11]. Gamification does not aim at redefining the business processes, but on affecting how they are experienced [12]. The underlying software plays an important role as it allows to automate tracking participants' actions, register their achievements, and pass relevant feedback [13].

The paper aims to provide answers to the three basic questions: what actually forms the applied gamification, what can be the reasons for making use of it in Enterprise Information Systems, and how to implement it there properly. The structure of the paper has been modeled appropriately into three sections, ending with the conclusion.

\section{WHAT THE APPLIED GAMIFICATION CONSISTS OF}

Although a definition of gamification has already been provided, even the reading of thirty definitions gathered by

The publication was financed from the funds of the Department of Engineering of Information Systems at the Faculty of Economics and Management of University of Szczecin for maintaining research potential.
Andrzej Marczewski [2] does not tell what a gamified system actually consists of. In order to explain that, it is necessary to look at the actual components of gamification.

One of the most widely known lists of gamification elements is the one devised by Kevin Werbach and Dan Hunter [14]. They classify them into dynamics ("the bigpicture aspects of the gamified system"), mechanics ("the basic processes that drive the action forward and generate player engagement"), and components (the "more-specific forms that mechanics or dynamics can take").

The dynamics include:

- constraints - limitations or forced trade-offs,

- emotions driving players, such as: curiosity, competitiveness, frustration, happiness etc.,

- narrative - the storyline of the game,

- progression, measuring players' development,

- relationships - players' social interactions.

The mechanics include:

- challenges - tasks that require effort to solve,

- chance, bringing in randomness to the game,

- competition between players or groups of them,

- cooperation, requiring players to work together to achieve a shared goal,

- feedback providing players with information about how they are doing,

- $\quad$ resource acquisition - allowing players to gather useful or collectible items,

- rewards given for some action or achievement,

- transactions - allowing item trading between players,

- turns - sequential participation by players,

- win/loss/draw states - objectives that make one player/team the winner and the others the losers.

What Werbach and Hunter call components includes:

- achievements - defined objectives,

- avatars - player's character visual representation,

- badges - visual representations of achievements,

- boss fights - rare, extremely hard challenges,

- collections - sets of items/badges to accumulate,

- combat - a defined battle, typically short-lived,

- content unlocking - additional game content available after players reach certain objectives, 
- gifting - players' ability to share their resources,

- leaderboards that visually present player's achievements in relation to other players,

- levels that define steps in players' progression,

- points which measure players' progression,

- quests - sets of tasks with objectives and rewards,

- social graphs that represent players' network of contacts within the game,

- teams - groups of cooperating players,

- virtual goods, which have perceived value.

A much more comprehensive list of gamification components can be found in the Octalysis framework developed by Yu-Kai Chou [15]. He clusters them into eight categories, labeled as "core drives" of gamification.

The first drive is epic meaning \& calling. Its components help players justify devoting their time to the game. They are supposed to make players believe that they are doing something great (narrative, higher meaning) or were "chosen" to do something (elitism, humanity hero, destiny child), or that they have got some gift that others have not (beginners luck, free lunch). Players may also feel attached to the game world elements they created (co-creator).

The development \& accomplishment components exploit the players' internal drive to make progress in absolute (points, progress bar) or relative terms (leaderboards), acquire (step-by-step tutorial) and develop skills (with badges as achievement symbols), overcome challenges (chosen from quest list, or the final boss fights), and receive due appreciation for it (fixed action rewards, win prize, high-five, crowning, level-up symphony, aura effect).

The empowerment of creativity \& feedback components give players the decisive power (general's carrot) and engage them in a creative process, where they have to repeatedly figure things out (evergreen mechanics, blank fills) and try different combinations (real-time control, chain controls) possibly using approaches unavailable earlier (milestone unlock, boosters) after receiving instant feedback or hints (choice reception). They may also have a chance to opt out of a given challenge (voluntary autonomy).

The ownership \& possession components give players the feeling of owning something (virtual good, avatar), so that they want to make what they own better (build from scratch) while progressing in the game (learning curve) and own even more (earned lunch, collection set). The players' attachment to their belongings can be augmented by letting them constantly observe what they have (monitoring) and have them protect it from dangers (protection). The feeling of possession can also be extended to other players one has invited to the game (recruitment).

The social influence $\&$ relatedness components refer to activities inspired by what other people think, do, or say as well as the desire to draw closer to people, places, or events that players can relate to. It includes making personal relations publicly observable (friending), having veteran players as guides (mentorship, which also makes the beginner players more attached to the specific culture, as well as helps veteran players stay engaged in the game), cooperating with other players to solve difficult challenges (group quest), showing other players one's accomplishments, either explicitly (bragging) or implicitly (touting), having a place to chat about a variety of topics (water cooler), gifts or rewards that players can only receive from other players (social treasure), encouraging players to generously give, expecting the recipients to give back somehow (thank-you economy), and making social interactions technically very easy to perform (social prod).

The scarcity $\&$ impatience components address the human tendency to want things they cannot have. They include constantly showing an item that a player cannot easily get (dangling), having something accessible only at specified time (appointment dynamics), or in fixed intervals, or after meeting specified conditions (moats), showing time after which something becomes inaccessible (countdown), changing the pace at which progress can be made (throttles), and requiring players to collect multiple pieces to earn the actual reward (prize pacing).

The unpredictability \& curiosity components exploit the human infatuation with experiences that are uncertain and involve chance and the natural curiosity to explore. They include surprises (Easter eggs), also in form of unexpected rewards (sudden rewards), oracle effect that makes player expect an event to happen in the future (and wonder whether it will actually happen), quests within quests (mini quests), glowing choice which leads players in the right direction by appealing to their curiosity, lotteries that some player has to win each period, with actions available that increase one's chance (rolling rewards), random rewards that recreate the excitement that children have opening gift boxes, and playing small pranks on players (mischief).

The loss \& avoidance components motivate players with a threat of losing something they have attained. They include sunk-cost tragedy (players continue the game, because they spent a lot of time playing so far), progress loss (if players stop playing, they lose what they earned), fear of missing out (players are aware that when they do not participate, things happen that could benefit them), evanescence opportunity (which will disappear if a player does not perform certain action), scarlet letter (a shame of not having something all the good players have), status quo sloth (wanting to continue the game with the same behavior), and marking the loss in a special way (weep tune and visual grave).

\section{Why APPLY GAMIFICATION TO EIS}

There are various reasons given why gamification can be helpful for an enterprise. The primary argument is the link between games and intrinsic motivation, which can be exploited with gamification. All the seven main intrinsic motivators identified by Thomas W. Malone and Mark R. Lepper (i.e., challenge, curiosity, control, fantasy, cooperation, competition and recognition $[16$, p. 230 and 
242]) can be effectively addressed in a gamified system (see section II). And that the lack of motivation is a serious issue in enterprises can be seen, e.g., from the results of the longterm Gallup poll showing that $70 \%$ of American workers are not engaged at work [17].

There are also other reasons provided in the literature (see e.g. [18] and works cited therein). One is the lack of goal prioritization making employees overladen with both present activities and development opportunities losing interest in taking actions that are not needed at the moment, but will be crucial in the future. A gamified system can both rank the possible actions in terms of their relative value to the enterprise, and provide a path of development to follow.

The second reason is the coming of the new generation of employees: Generation Z, digital natives, who have different expectations from work and communication habits than previous generations. A gamified system can use the type of communication they are familiar with, and work as a bridge between them and the older employees.
Another one is the omnipresence of stress in many corporate environments, which leads to lower productivity, problems with interpersonal communication, and even physical and psychic health issues. A well-designed gamified system can both address some causes of stress (with its informal communication and a clear system of priorities) and aid in stress relief (with relaxing side activities and moodimproving feedback it offers).

Regardless of what the reason is, there are numerous examples of successful enterprise gamification [19].

Moving on to the details of gamification in Enterprise Information Systems, Table I lists its possible uses grouped in four categories, consisting of those related to the improvement of: work performance, work attitude, social relations, and on-boarding and training processes. Note that the list is not exhaustive, as it is up to the creativity of a designer to find a combination of gamification components that would address particular goals that the enterprise management may consider important.

TABLE I.

POSSIBLE USE OF GAMIFICATION IN EIS

\begin{tabular}{|c|c|c|}
\hline Practice & Expected benefit & Relevant component \\
\hline \multicolumn{3}{|c|}{ Performance } \\
\hline Bundle tasks and split rewards & $\begin{array}{l}\text { Users are motivated to work consistently, and } \\
\text { complete related tasks together }\end{array}$ & $\begin{array}{l}\text { Collection set, Prize } \\
\text { pacing }\end{array}$ \\
\hline $\begin{array}{l}\text { Define rush hours when productivity is most } \\
\text { needed }\end{array}$ & $\begin{array}{l}\text { Users should increase their effort at the right } \\
\text { time }\end{array}$ & $\begin{array}{l}\text { Appointment dynamics, } \\
\text { Fixed intervals }\end{array}$ \\
\hline $\begin{array}{l}\text { Differentiate the rewards for completing } \\
\text { various tasks }\end{array}$ & $\begin{array}{l}\text { Users are directed to the most important tasks at } \\
\text { a given moment }\end{array}$ & $\begin{array}{l}\text { Fixed action rewards, } \\
\text { Virtual good }\end{array}$ \\
\hline Mark very hard tasks & Users can prepare better for a big challenge & Boss fights \\
\hline Reward what every user should do & Users are motivated to catch up with others & Scarlet letter \\
\hline Visualize relative employees' performance & Users are motivated to rise over others & Leaderboards \\
\hline Visualize the distance to the goal & Users are motivated to finish the current task & Progression bar \\
\hline Visualize the time left & Users are motivated to hasten their work & Countdown \\
\hline \multicolumn{3}{|c|}{ Work attitude } \\
\hline Announce crucial events that will come later & Users are curious of what will actually happen & Oracle effect \\
\hline $\begin{array}{l}\text { Define penalties for failing to complete a } \\
\text { task }\end{array}$ & $\begin{array}{l}\text { Users appreciate what they have attained and } \\
\text { could lose }\end{array}$ & $\begin{array}{l}\text { Points, Protection, } \\
\text { Progress loss }\end{array}$ \\
\hline Leave users some degree of freedom & Users feel they have control of what they do & $\begin{array}{l}\text { General's carrot, } \\
\text { Voluntary autonomy }\end{array}$ \\
\hline Let users improve or customize the system & Users feel attached to what they created & Co-create \\
\hline Provide a chance of surprise & The monotony of repetitive tasks is shunned & $\begin{array}{l}\text { Easter eggs, Random } \\
\text { rewards, Mischief }\end{array}$ \\
\hline Provide a chance to shine for everyone & $\begin{array}{l}\text { Even lagging users can have their moment of } \\
\text { glory }\end{array}$ & Rolling rewards \\
\hline Remind users the importance of their role & $\begin{array}{l}\text { Users are aware of the value of their } \\
\text { contribution }\end{array}$ & Elitism, Humanity hero \\
\hline Remind users the enterprise mission & $\begin{array}{l}\text { Users feel they are part of something big and } \\
\text { good }\end{array}$ & Higher meaning \\
\hline $\begin{array}{l}\text { Reward completion even of the simplest } \\
\text { tasks }\end{array}$ & Users feel their effort is recognized & $\begin{array}{l}\text { Fixed action rewards, } \\
\text { Virtual good, High-five }\end{array}$ \\
\hline
\end{tabular}


TABLE I (CONTINUED).

POSSIBLE USE OF GAMIFICATION IN EIS

\begin{tabular}{|c|c|c|}
\hline Practice & Expected benefit & Relevant component \\
\hline $\begin{array}{l}\text { Visualize how the results of repetitive tasks } \\
\text { accumulate }\end{array}$ & $\begin{array}{l}\text { Users comprehend the magnitude of their } \\
\text { everyday work }\end{array}$ & Points, Progression bar \\
\hline Visualize possible big rewards & $\begin{array}{l}\text { Users are aware of what they can gain if they } \\
\text { stay engaged }\end{array}$ & Dangling \\
\hline Visualize the progress a user has made so far & $\begin{array}{l}\text { Users comprehend the progress they made } \\
\text { which should increase their self-esteem }\end{array}$ & $\begin{array}{l}\text { Levels, Badges, } \\
\text { Monitoring }\end{array}$ \\
\hline \multicolumn{3}{|c|}{ Social relations } \\
\hline Let employees collaborate on tasks & $\begin{array}{l}\text { Arduous tasks can be finished on time and } \\
\text { knowledge is transferred from the more to the } \\
\text { less experienced users }\end{array}$ & Group quest \\
\hline Let users boast their accomplishments & Users can share their gladness with others & Bragging, Touting \\
\hline Let employees visualize their relations & Social relations are improved & Friending \\
\hline Let users discuss freely & $\begin{array}{l}\text { Users get to know each other, share } \\
\text { experiences and ideas }\end{array}$ & Water cooler \\
\hline Let users help each other & $\begin{array}{l}\text { Knowledge is transferred from the more to } \\
\text { the less experienced users and their social } \\
\text { relations are improved }\end{array}$ & Thank-you economy \\
\hline Let users reward each other & $\begin{array}{l}\text { Users feel their effort is recognized and their } \\
\text { social relations are improved }\end{array}$ & $\begin{array}{l}\text { Social treasure, Virtual } \\
\text { good }\end{array}$ \\
\hline Make it fast and easy to interact with others & $\begin{array}{l}\text { Social interactions do not hurt productivity } \\
\text { much }\end{array}$ & Social prod \\
\hline \multicolumn{3}{|c|}{ On-boarding and training } \\
\hline $\begin{array}{l}\text { Appoint more difficult tasks to users as they } \\
\text { make progress }\end{array}$ & $\begin{array}{l}\text { Users do not get bored or frustrated with tasks } \\
\text { that are too easy or too hard for them }\end{array}$ & $\begin{array}{l}\text { Milestone unlock, } \\
\text { Learning curve }\end{array}$ \\
\hline $\begin{array}{l}\text { Celebrate passing important steps of } \\
\text { development }\end{array}$ & Users feel the progress they make matters & $\begin{array}{l}\text { Level-up symphony, } \\
\text { Aura effect }\end{array}$ \\
\hline Communicate action results immediately & Users know when they do well & Instant feedback \\
\hline Guide users in their steps & Users know what to do to progress & $\begin{array}{l}\text { Step-by-step tutorial, } \\
\text { Choice reception }\end{array}$ \\
\hline Introduce users to the organizational culture & Users adapt faster to the organization & Narrative \\
\hline Let experienced users guide new ones & $\begin{array}{l}\text { Knowledge is transferred from experienced to } \\
\text { novice users and social relations are created }\end{array}$ & Mentorship \\
\hline Make the first steps easier for beginner users & Users get a positive first impression & $\begin{array}{l}\text { Beginners luck, Free } \\
\text { lunch, Boosters }\end{array}$ \\
\hline $\begin{array}{l}\text { Make users improve their weak sides before } \\
\text { they can move on }\end{array}$ & Users' skill development is more balanced & Moats \\
\hline
\end{tabular}

\section{HOW TO PROPERLY IMPLEMENT GAMIFICATION IN EIS}

The successful implementation of gamification in EIS is a matter of primary importance, as a failed attempt will bring costs in morale and productivity, notwithstanding the cost of the implementation itself.

It is therefore strongly advised to carry it out in a carefully planned manner. The first thing is to follow a proven procedure, such as the player experience design process proposed by Brian Burke [1], which includes seven steps respectively devoted to: (1) business outcomes and success metrics, (2) target audience, (3) player goals, (4) engagement model, (5) play space and journey, (6) game economy, and (7) repetitive playing and testing (highly possibly leading back to one of the previous steps).
Mario Herger convincingly argues that gamification should be focused on value creation for the players, and only through it the value for the organization should be created [20]. While the player's value creation does not automatically translate into an organization's value creation, but also the value created for an organization may be larger than the value for an individual player. He also lists three types of reactions that should be achieved with gamification: Aaah-effect (the act of delight), Aha-effect (the act of revelation) and the Haha-effect (the act of amusement).

Fabian Groh provides eleven design principles for implementing gamification [21]: (1) connect to personal goals, (2) connect to a meaningful community of interest, (3) create a meaningful story, (4) beware of social context 
meanings, (5) provide interesting challenges, (6) provide clear, visual, varying, and well-structured goals, (7) provide juicy feedback, (8) beware of unintended behaviors, (9) play is voluntary, (10) beware of losing autonomy, and (11) beware of devaluating activities.

Ethan Mollick and Nancy Rothbard highlight the role of consent, understood as the active cooperation of workers with managerial goals, owing to the fact that gamification is not driven organically by employees, but instead imposed from the top by managers [22, p. 14]. They therefore point to the importance of three indicators of consent, i.e. clearly understanding the rules of the game, perceived sense of justice and fairness, and active engagement.

The last aspect that needs to be addressed is the technology of implementation. The gamification subsystem can be developed as a module of an EIS or a separate gamification software that has to be integrated with the main system. A generic platform for enterprise gamification, based on service-oriented and event-driven principles, as well as best practices, and targeted for both modern and legacy systems, was proposed by Philipp Herzig et al. [23].

\section{CONCLUSION}

Gamification is able to make the employees' experience of performing tedious and repetitive tasks more enjoyable, rise their engagement, improve their attitude towards work, and, consequently, increase their productivity.

The rich portfolio of successful gamification projects makes it something too promising to ignore for enterprises in the world of scarce opportunities for gaining competitive advantage ( $c f$. the scarlet letter gamification component).

The Enterprise Information Systems, due to their prevalence in today's organizations, are viable points of implementation of gamification spanning over different business processes and addressing various types of employees' activity.

This paper provided answers what the gamification amounts to in practice (with a catalog of gamification components in section II), why it can be useful to implement it in an EIS (with explanations for why it can work and a list of possible uses in section III), and how to do it right (with implementation guidelines in section IV).

\section{REFERENCES}

[1] B. Burke, Gamify: how gamification motivates people to do extraordinary things. Brookline: Gartner, 2014.

[2] A. Marczewski, Defining gamification - what do people really think?, 2014, http://www.gamified.uk/2014/04/16/defininggamification-people-really-think. Retrieved 5 May 2016.

[3] K. Seaborn, D.I. Fels, „Gamification in theory and action: A survey,” International Journal of Human-Computer Studies, vol. 74, pp. 1431, 2015, http://dx.doi.org/10.1016/j.ijhcs.2014.09.006.

[4] B. Borowski, Gamification - Engage customers in your business: the hottest marketing trend in 2014. Luxembourg: CreateSpace, 2014.

[5] J. Swacha, "Gamification in Knowledge Management: Motivating for Knowledge Sharing," Polish Journal of Management Studies, vol. 12, no. 2, pp. 150-160, 2015.
[6] L.F. Rodrigues, C.J. Costa, A. Oliveira, "The adoption of gamification in e-banking," in Proceedings of the 2013 International Conference on Information Systems and Design of Communication. New York: ACM, 2013, pp. 47-55, http://dx.doi.org/10.1145/2503859.2503867.

[7] K.M. Kapp, The gamification of learning and instruction: Gamebased methods and strategies for training and education. San Francisco: Pfeiffer, 2012.

[8] O. Korn, M. Funk, A. Schmidt, "Design approaches for the gamification of production environments: a study focusing on acceptance," in Proceedings of the 8th ACM International Conference on PErvasive Technologies Related to Assistive Environments. ACM, New York, 2015, http://dx.doi.org/10.1145/2769493.2769549.

[9] A. Negruşa, V. Toader, A. Sofică, M. Tutunea, R. Rus, "Exploring gamification techniques and applications for sustainable tourism," Sustainability, vol. 7, no. 8, pp. 11160-11189, 2015, http://doi.org/10.3390/su70811160.

[10] F. Khatib, F. DiMaio, Foldit Contenders Group, Foldit Void Crushers Group, S. Cooper, M. Kazmierczyk, M. Gilski, Sz. Krzywda, H. Zabranska, I. Pichova, J. Thompson, Z. Popović, M. Jaskolski, D. Baker, "Crystal structure of a monomeric retroviral protease solved by protein folding game players," Nature Structural \& Molecular Biology, vol. 18, no. 10, pp. 1175-1177, 2011.

[11] M. Tabatabaie, R. Paige, C. Kimble, „Exploring Enterprise Information Systems," in M. Khosrow-Pour (ed.), Enterprise Information Systems: Concepts, methodologies, tools and applications. Hershey: IGI Global, 2011, pp. 35-52.

[12] N. Teh, D. Schuff, S. Johnson, D. Geddes, "Can work be fun? Improving task motivation and help-seeking through game mechanics," in R. Baskerville, M. Chau (eds.), Proceedings of the International Conference on Information Systems. Milan: AIS, 2013.

[13] J. Swacha, "An architecture of a gamified learning management system," in Y. Cao, T. Väljataga, J.K.T. Tang, H. Leung, M. Laanpere (eds.), New horizons in web based learning, Cham: Springer, 2014, pp. 195-203, http://dx.doi.org/10.1007/978-3-319-04954-0_24.

[14] K. Werbach, D. Hunter, For the win: How game thinking can revolutionize your business. Philadelphia: Wharton Digital Press, 2012.

[15] Y.-K. Chou, Actionable gamification: Beyond points, badges, and leaderboards. Fremont: Octalysis Media, 2016.

[16] T.W. Malone, M. R. Lepper, "Making learning fun: A taxonomy of intrinsic motivations for learning," in R. Snow, M.J. Farr (eds.), Aptitude, learning, and instruction. Volume 3: Conative and affective process analyses. Hillsdale: Lawrence Erlbaum, 1987, pp. 223-253.

[17] Gallup, State of the American Workplace, http://www.gallup.com/services/178514/state-americanworkplace.aspx, 2013. Retrieved 5 May 2016.

[18] K. Gruszecka, "Management through entertainment," in J. Swacha, K. Muszyńska (eds.), Information Technology Meets Management in Knowledge Economy. Warsaw: Polish Information Processing Society, 2015, pp. 139-158.

[19] Y.-K., Chou, A Comprehensive List of 90+ Gamification Cases with ROI Stats, 2015, http://yukaichou.com/gamificationexamples/gamification-stats-figures/\#.VzCedYSLSUk. Retrieved 5 May 2016.

[20] M. Herger, Enterprise Gamification. Engaging People by Letting Them Have Fun. Book 1. The Basics. Luxembourg: CreateSpace, 2014.

[21] F. Groh, "Gamification: State of the art definition and utilization", in N. Asaj, B. Könings, M. Poguntke, F. Schaub, M. Weber, B. Wiederscheim (eds.), Proceedings of the 4th Seminar on Research Trends in Media Informatics. Ulm: Institute of Media Informatics, 2012, pp. 39-46.

[22] E.R. Mollick, N. Rothbard, "Mandatory Fun: Consent, Gamification and the Impact of Games at Work," The Wharton School Research Paper Series, 2014, http://dx.doi.org/10.2139/ssrn.2277103.

[23] P. Herzig, M. Ameling, A. Schill, ,A Generic Platform for Enterprise Gamification," in 2012 Joint Working IEEE/IFIP Conference on Software Architecture and European Conference on Software Architecture. Helsinki: IEEE, 2012, pp. 219-223. 